\title{
Convergence as a Structural Goal of Sustainable Economic Development: the Overview of Approaches
}

\author{
Sergey Zhironkin ${ }^{1,2 *}$, Olga Zhironkina ${ }^{3}$, and Michal Cehlar ${ }^{4}$ \\ ${ }^{1}$ Siberian Federal University, 660075 Lida Prushinskaya St. 2, Krasnoyarsk, Russia \\ ${ }^{2}$ T.F Gorbachev Kuzbass State Technical University, 650000, 28 Vesennya St., Kemerovo, Russia \\ ${ }^{3}$ Kemerovo State University, 650043, 6 Krasnaya St., Kemerovo, Russia \\ ${ }^{4}$ Technical University in Kosice, Institute of Earth Resources, Faculty of Mining, Ecology, Process \\ Control and Geotechnologies, Park Komenského 19, 042000 Košice, Slovakia
}

\begin{abstract}
The processes of a green economy development, changes in approaches to the production and use of energy, the emergence of new sources of investment in the technological transition - all this is a consequence and, at the same time, the cause of structural shifts in the economies of advanced countries. In this light, the technological backwardness of the Russian economy, caused by a negative structural shift during the period of market reforms, impedes the transition to a green economy, rationalization of the use of natural resources and reduction of environmental pollution. Therefore, the development of theoretical provisions for the convergence of environmental and economic policies, the development of appropriate incentives for business are considered as an important step in the transition to sustainable development. For this purpose, the authors examine the original approaches to various paths of transition to sustainable development caused by structural shifts of a convergent nature in the economy.
\end{abstract}

\section{Introduction}

Economic crises that have become more frequent in recent decades, as well as manmade disasters on a global scale, indicate the dominance of the model of unsustainable development [1]. Its key drawback is the absolute priority of economic growth to the detriment of solving a complex of environmental and social problems, the lack of coordination of goals, objectives, tools and expected results in regulation of production, consumption and nature management [2]. At the same time, back in the mid-1980s - early 1990s within the framework of the UN structures, new conceptual approaches to the development of society and the economy have been formed, in particular, two new theories that had a great impact on the discussion of new models: sustainable development and human development [3]. Despite the difference in theoretical approaches, in the center of these concepts is a man, not nature, therefore, despite the declarative goal of sustainable growth and development, progress in

* Corresponding author: zhironkin@inbox.ru 
their practical implementation in the world is insignificant [4]. In this regard, we can talk about the lack of convergence of economic and environmental policies, both at the national and global levels [5].

One of the reasons for the preservation of the traditional type of economic development, with its weak sensitivity to social and environmental problems, has become insufficient attention to the long-term consequences of the increased pressure on the environment in the process of accelerating economic growth. Moreover, the ongoing economic convergence of developed and developing countries intensifies the environmental degradation in the latter, due to the over-exploitation of natural resources [6]. In general, the economic mainstream is within the framework of the traditional paradigm of economic growth, which is well traced in the development programs of the overwhelming majority of countries in the world, including Russia. It is no coincidence that ahead of the UN Conference on Sustainable Development, the Report of the High Level Panel of the UN Secretary General on Global Sustainability "Sustainable Planet of Sustainable People: the future we choose" notes the need to develop a new "political economy of sustainable development". It will allow transferring the paradigm of sustainable development from the periphery global economic debate at their center $[3,5]$. In our opinion, this idea can be implemented within the framework of the green economy concept.

\section{Materials and Methods}

Economic development based on environmental degradation and depletion of natural resources cannot be sustainable in the long term. In this regard, there is an intensified search for a new model of sustainable development in the world. In this context, the most widespread both in theory and in practice are new models of an environmentally oriented economy [3]:

- green economy and green growth,

- low-carbon economy,

- bioeconomy,

- blue economy,

-circular economy.

At the same time, we believe that all these types of environmentally oriented economies have a common basis - profound structural changes affecting technology, reproduction, regulation. The latter implies the convergence of environmental, industrial and economic policies into a single system for supporting sustainable development.

The low-carbon economy is developing as a part of the fight against global climate change and the reduction of greenhouse gas emissions. The advanced countries are demonstrating great structural and technological shifts aimed at reducing the consumption of traditional hydrocarbons. The share of renewable energy sources is sharply increasing, which is supported by various economic instruments - taxes, loans, subsidies, etc. For the Russian context, the global low-carbon trend is important because of the clearly declared priorities for reducing the consumption of traditional hydrocarbons by the main consumers of the country's energy resources: the countries of the European Community and China. Already now, the share of renewable energy sources in electricity production in our leading importer of hydrocarbons - Germany has reached almost 40\% [3]. In Russia, low-carbon trends should manifest themselves, in the author's opinion, primarily in a sharp decrease in the energy intensity indicator, energy consumption per unit of the final result. Despite all attempts, in Russia this indicator continues to be one of the highest in the world, exceeding the rational levels in 2-3 times [3].

The importance of the accelerated development of a circular economy (or an economy of complete cycle) is dictated by the continuous production and accumulation of waste. The established traditional linear economy has obviously exhausted itself from an ecological and 
social standpoint. Decisions made on a global scale in recent years have contributed to the creation of a waste management industry, but this is only the first step towards a circular economy [3].

Bioeconomics is associated with the rapid development of the sixth technological mode in the world, in which biotechnologies occupy an important place, which are convergent and combine pharmaceuticals, agriculture and forestry, and organic chemistry.

At present, in the world from the part of states and businesses, there is a growing interest in the development of such a new model as blue economy model. It (coastal areas, seas and oceans) includes both already formed sectors and types of activities (fishing and processing of fish, shipping, port facilities, shipbuilding and repair, sea tourism, offshore oil and gas production, etc.), and innovative (aquaculture, marine biotechnology, wind energy facilities in water areas, energy of sea and ocean tides, etc.) [3]. For Russia, with its largest coastline in the world, the balanced development of many "water" sectors and activities is extremely essential. It is enough to give examples of the Far Eastern and Arctic regions with their large economic potential.

Consequently, the category of a green economy covers the structural, technological and territorial aspects of the above models. At the same time, often the green economy means only activities in the field of environmental protection and compensation for environmental damage, which covers the production of various types of treatment equipment, utilization of secondary resources and waste, provides environmental services, etc. In this case, the green economy is a part of the national economy in general. At the same time, it is obvious that the coexistence of such green economy (as separate industries) and nature-intensive national economy (as a single system) is impossible. For example, for Russia, the preservation of trends for the extensive development of energy and metallurgy with the fastest development of green business will lead to the preservation of an overall raw material export and an unstable model of the economy [7]. Thus, "green" transformations should cover the entire economy, and greening processes can ultimately be effective only at the macro level [3].

\section{Results and Discussion}

For the transition to the green economy, Russia will need a period of structural transformation and modernization of the economy, technological changes, and the formation of a new model of reproduction [8]. An important task is to reduce the costs of such a transition and radically increase the efficiency of using natural resources in two directions [3]:

1. Increasing the efficiency of regulation of nature management by the state in the field of resource extraction and use. With the help of economic and legal instruments (taxes, fees, tariff policy, fines, compliance with norms and standards, etc.), it is possible to stimulate state and private monopoly companies to improve the efficiency of the use of natural resources, to compensate for external costs and environmental damage.

2. Development of competition between manufacturers, overcoming the monopoly in the energy sector to reduce costs, stimulate enterprises to nature-saving innovations, diversify production, deep processing of raw materials. As a result of these measures, an increase in energy efficiency and a decrease in the nature intensity of products are expected due to the introduction of new technologies [9].

An important task of macroeconomic policy should be financial support for greening the economy and green growth, including the use of specialized environmental taxes, loans, subsidies, customs duties, and insurance. Obviously, the tax system should be transformed taking into account the goals of sustainable development, diversification and modernization of the economy, therefore, maximum taxes should be imposed on nature exploiting and polluting activities while minimizing the tax burden on the processing, high-tech and infrastructure sectors [3]. It is necessary to invest in improving the use of already exploited 
natural resources and protecting the environment based on modernizing the economy, supporting innovation, replacing nature-intensive technologies with resource-saving and energy-efficient (best available technologies), deepening and diversifying the processing of raw materials, etc.

In the system of convergence of economic and environmental policies, the experience of European countries shows that the management of the green supply chain is becoming a key area of greening the activities of enterprises [10]. It should be noted that with the greening of a business, the business strategy becomes hybrid in nature. Organizations must focus on making the best use of resources and energy to build sustainable supply chains. It is about cutting costs while caring for the environment.

Despite the seeming incompatibility of these goals, they are quite harmonious, but require a change in managerial thinking, as well as technological innovation renewal not only in production, procurement, sales, etc., but also in management [10]. Integration of the green supply chain management, in our opinion, will form the basis of a modernized sustainable business strategy for successful companies in the near future. Building a green supply chain can help reduce greenhouse gas emissions. It is worth noting that investments in improving the environmental aspects of the supply chain will allow an entire industry (and sometimes several related industries) to reduce emissions, modernize production and, as a result, increase the competitiveness of companies.

Enhancing the environmental effect is possible within the digitalization of green supply chains, which is designed to simplify the processes of their regulation, make them more understandable and transparent, observable, i.e., ultimately, increase their manageability and allow making effective management decisions.

In fact, the combination of the concepts of sustainable development and the developing digital revolution is becoming a response to the challenge of a society interested in the environmental transformation of businesses, regardless of their size, industry and territorial location (environmental problems are especially acute in large cities most polluted by anthropogenic emissions, temperature anomalies, industrial and household noise, etc.) [10].

Digitizing a green supply chain enables company management to green the entire supply chain from development and implementation to transportation and sale to customers, as well as the subsequent possible disposal of the product itself, or the waste arising from its intended use. Thus, companies can avoid the transfer of adverse environmental impacts from one stage of the life cycle to another, and green supply chain management can be implemented in almost any industrial enterprise [10]. One of the ways to implement this concept is to analyze the existing supply chain for the possibility of introducing tools of sustainable development at each stage of this chain.

\section{Conclusion}

A review of approaches to understanding the processes of the formation of the green economy showed that the initiation of a convergent structural shift that brings the Russian economy closer to technologically and ecologically advanced systems is the starting point for the transition to sustainable development. This, in turn, requires the formation of a convergent environmental and economic policy aimed at increasing the efficiency of natural resource management in the field of mining and using minerals and the development of competition between producers of energy and recycled raw materials. Green supply chain management should be an effective tool for convergent environmental and economic policies. 


\section{References}

1. S.M. Sukhorukova, A.M. Pogorely, A.V. Samorokov, Economics and Innovation Management, 2, 45-53 (2020)

2. S.M. Sukhorukova, A.M. Pogorely, A.V. Samorokov, Economics and Innovation Management, 1, 54-65 (2020)

3. S.N. Bobylev, P.A. Kiryushin, O. V. Kudryavtseva, Green Economy and Sustainable Development Goals for Russia: Collective Monograph (MSU, Moscow, 2019)

4. M. Cehlar, Economics and Innovation Management, 3, 24-31 (2019)

5. UN Development programme. URL: https://www.undp.org/content/undp/en/home/

6. S. Zhironkin, S. Demchenko, G. Kayachev, E. Taran, O. Zhironkina, E3S Web Conf. 105, 03008 (2019)

7. E.A. Taran, Convergent structural shifts in the economy: thesis (SFU, Krasnoyarsk, 2020)

8. V.V. Guzyr', Economics and Innovation Management, 4, 4-19 (2019)

9. M.A. Klimovich, M.A. Gasanov, Economics and Innovation Management, 2, 8-17 (2019)

10. A.N. Kazantseva, Convergence of public policy and environmental management (Kursk branch of the Financial University under the Government of the Russian Federation, Kursk, 2020) 